\title{
SISTEM RESI GUDANG KOPI ARABIKA GAYO DALAM PERSPEKTIF KELEMBAGAAN PENGELOLA DAN PENGGUNA DI KABUPATEN ACEH TENGAH
}

\author{
Keumala Fadhiela ND $^{\left.1^{*}\right)}$, Dwi Apriyani ${ }^{2)}$ \\ ${ }^{1}$ Program Studi Agribisnis, Fakultas Pertanian Universitas Teuku Umar \\ ${ }^{2}$ Program Studi Agribisnis, Fakultas Pertanian Universitas Siliwangi \\ ${ }^{*}$ Corresponding author : keumalafadhiela@utu.ac.id
}

To cite this article:

Fadhiela ND, K., \& Apriyani, D. (2020). Sistem Resi Gudang Kopi Arabika Gayo dalam Perspektif Kelembagaan Pengelola dan Pengguna di Kabupaten Aceh Tengah. JIA (Jurnal IImiah Agribisnis) : Jurnal Agribisnis dan IImu Sosial Ekonomi Pertanian, 5(2), 42 - 50. doi:http://dx.doi.org/10.37149/jia.v5i2.11558

Received: March 21, 2020; Accepted: April 16, 2020; Published: April 20, 2020

\begin{abstract}
The problem of agricultural marketing in Indonesia that often occurs is the limited access to capital and falling prices during the main harvest. Therefore, the Warehouse Receipt System (WRS) is a solution for farmers because it can delay sales, protect value, and guarantee commodity prices. Coffee WRS in Central Aceh District has generated funding through 2.5 billion warehouse receipts. However, the interest of coffee farmers to get involved in WRS activities is still very low. The writing of this paper aims to analyze qualitative descriptive information, implementation, and evaluation materials for the government in the implementation of the Gayo Arabica coffee WRS program in Central Aceh District. The study uses qualitative and tiered methods of WRS information using primary and secondary data. The results showed that most farmers found it difficult to meet SRG quality and quality standards so that it also influenced the interest of farmers in the WRS involvement which was still low. Quality assurance and quality become the main attraction for farmers to participate, so WRS activities need to be supported in improving facilities and infrastructure. Public understanding of WRS is still limited so massive socialization is needed. The active role of local government in developing the WRS business also needs to be increased to produce higher WRS productivity
\end{abstract}

Keywords: agriculture; farmer; government; infrastructure; system

\section{PENDAHULUAN}

Salah satu permasalahan pemasaran pertanian di Indonesia yang seringkali terjadi yaitu terbatasnya aksesibilitas petani untuk mendapatkan sumber permodalan dari pihak perbankan. Petani diharuskan mempunyai agunan yang diperlukan untuk memperoleh pinjaman uang misalnya berupa tanah, kendaraan, dan lain-lain. Permasalahan ini kerap terjadi hampir di semua produsen komoditas pertanian. Sementara itu, komoditas pertanian sendiri sangat rentan menghadapi fluktuasi harga dimana ketika panen raya harga akan turun, sedangkan dalam masa paceklik, harga melonjak tinggi. Kondisi ini merugikan petani karena penerimaan petani atas hasil panen justru menjadi rendah padahal petani memerlukan uang tunai untuk memenuhi kebutuhan hidup sehari-hari, membayar utang, dan untuk modal usahatani selanjutnya (Haryotejo, 2013). Oleh karena itu, diperlukan peran pemerintah dalam mengendalikan harga, misalnya pembelian oleh Bulog untuk Cadangan Beras Pemerintah.

Setidaknya terdapat suatu solusi yang dipercaya mampu membantu petani ketika terjadi kemerosotan harga jual pada saat panen raya yaitu sistem tunda jual melalui Sistem Resi Gudang (SRG). SRG memperkuat cadangan pangan sekaligus sebagai sarana stabilisasi harga pangan yang dapat meningkatkan perekonomian daerah dan nasional. Sedangkan disegi sistem pembiayaan, SRG banyak memberikan manfaat pada petani terutama pada akses permodalan. Oleh karena itu, SRG menjadi solusi alternatif bagi petani karena menjadi instrumen manajemen resiko (tunda jual, lindung nilai dan jamin harga). Petani mendapatkan harga yang lebih baik karena menunda jual, mendapatkan kepastian kualitas dan kuantitas atas komoditas yang disimpan serta mendorong 
berusaha secara berkelompok sehingga memperkuat bargaining position petani. Selain itu, petani juga memperoleh kemudahan akses pinjaman melalui dokumen resmi berupa Resi Gudang (RG) yang dapat dijadikan jaminan kredit (collateral) sehingga petani dapat memenuhi kebutuhan seharihari dan menjadi modal untuk usahatani selanjutnya.

Salah satu komoditi yang dapat disimpan di gudang SRG adalah kopi. Kopi menjadi komoditi yang dipertimbangkan masuk dalam SRG karena produksi kopi di Indonesia yang tinggi. Pada tahun 2017 produksi rata-rata kopi Arabika Provinsi Aceh mencapai 189,74 ribu ton dan menduduki peringkat pertama di Indonesia sejak tahun 2015 hingga tahun 2019 yang mencapai 55.885 ton (Direktorat Jenderal Perkebunan [DITJENBUN], 2019). Oleh karena itu, diharapkan potensi keuntungan yang diperoleh melalui skema SRG di Provinisi Aceh sangat tinggi dan memberikan banyak manfaat bagi petani. Sistem Resi Gudang Kopi Arabika Gayo mencapai nilai transaksi RG tertinggi yaitu 15,4 Milyar di tahun 2015 dan merupakan satu-satunya SRG yang sukses menghasilkan pembiayaan melalui Resi Gudang sebesar 27.2 Milyar untuk komoditas kopi di Indonesia (Badan Pengawas Perdagangan Berjangka Komoditi [BAPPEBTI], 2020).

Keberhasilan SRG Kopi Arabika Gayo di Kabupaten Aceh Tengah yang dibangun dengan Dana Alokasi Khusus (DAK) diinisiasi oleh Bappebti sejak tahun 2012 dan aktif sejak tahun 2014. Namun pada pelaksanaannya, SRG di Kabupaten Aceh Tengah tidak seluruhnya dimanfaatkan secara optimal oleh para petani kopi Arabika Gayo. Padahal RG menjadi instrument stablilisasi harga dan sebagai alternatif pembiayaan yang penting bagi petani. Pemasyarakatan tentang SRG maupun implementasi di lapangan belum sepenuhnya berjalan sesuai harapan, termasuk hubungan antar pelaku dan kelembagaan serta fasilitas terkait (Anugrah, Ewidodo, \& Suryani, 2015). Hal ini juga dinyatakan pada penelitian (Fadhiela, Rachmina, \& Winandi, 2018) bahwa minat petani kopi Arabika Gayo masih tergolong rendah untuk memanfaatkan SRG yaitu hanya 15\% hingga 20\% dari jumlah petani kopi Arabika di Kabupaten Aceh Tengah. Kurangnya minat petani ini dipengaruhi oleh perkembangan aktivitas/ kegiatan SRG yang masih berjalan lambat jika dibandingkan dengan potensi produksi kopi yang dihasilkan di Kabupaten Aceh Tengah yaitu 32.039 ton pada tahun 2018 (Badan Pusat Statistik, 2019).

Berdasarkan pengembangan SRG jangka panjang yang dicanangkan oleh Kementerian Perdagangan dan Bappebti (tahun 2020-2025) terdapat tiga target yang harus dicapai yaitu pertama, adanya pengembangan komoditi SRG yang diperdagangkan di bursa dan tidak terbatas pada komoditas pertanian. Kedua, adanya perluasan jaringan Gudang SRG yang tersebar diseluruh nusantara, dan ketiga, adanya sosialisasi dan edukasi yang berkelanjutan untuk menjaga integritas pelaksanaan SRG. Namun pada kenyataanya, hasil kajian yang dilakukan (Ashari, 2012) bahwa terdapat banyak masalah pada impelementasi SRG di Indonesia yaitu besarnya biaya transaksi, inkonsistensi kuantitas dan kualitas produk pertanian, minimnya dukungan perbankan dan masih lemahnya kelembagaan petani. Proses pelaksanaan SRG di Indonesia masih menghadapi permasalahan dari segi pengelola maupun pengguna di setiap daerah yang menjalankan program SRG. Pernyataan ini sesuai dengan hasil penelitian (Erwidodo, Suryani, \& Anugrah, 2014), (Ashari, E., Y., A., \& Suharyono S., 2013) dan (Ariyani, 2008) bahwa secara umum kendala pelaksanaan SRG di Indoensia dikarenakan kurangnya fasilitas gudang yang standar, alat pengering serta alat pengemasan yang terbatas.

Kajian ini perlu dilakukan untuk mengetahui bagaimana penyelenggaraan SRG dilaksanakan terutama pada SRG kopi Arabika Gayo di Kabupaten Aceh Tengah berdasarkan pendekatan kelembagaan pengelola maupun pengguna. Penelitian ini bertujuan untuk menganalisis secara deskriptif tentang kebijakan penyelenggaraan SRG dan memberikan informasi mengenai program SRG di Kabupaten Aceh Tengah. Selain itu, penelitian ini juga diharapkan menjadi bahan evaluasi bagi pemerintah dalam pelaksanaan program SRG agar tepat sasaran sehingga tercapai tujuan yang diharapkan dimasa yang akan datang

\section{MATERI DAN METODE}

Penelitian tentang Analisis Kebijakan dan Kinerja SRG dilakukan dengan metode penelitian kualitatif dan berjenjang yang didasarkan dari sumber informasi SRG. Lokasi penelitian dilakukan di Kabupaten Aceh Tengah yang merupakan satu-satunya SRG komoditas kopi di Provinsi Aceh yang masih aktif. Penelusuran data dan informasi tentang keterkaitan kelembagaan pengelola maupun pengguna SRG dilakukan dengan mengikuti alur penelusuran informasi dari masing-masing partisipan utama yang terkait dengan topik penelitian. Adapun partisipan utama penelitian diantaranya Pengelola Gudang yaitu Direktur Utama PT. Ketiara (1 orang) dan Penanggung Jawab Gudang (1 orang), Ketua Kelompok Tani (5 kelompok tani), seluruh petani anggota (40 orang), Pihak Bank Penanggung Jawab Pembiayaan SRG (1 orang) serta dinas terkait yaitu ketua Dinas 
Perindustrian, perdagangan dan Koperasi Kabupaten Aceh Tengah (1 orang) sebagai lembaga yang terkait dengan penyelenggaraan SRG di Kabupaten Aceh Tengah. Materi yang digunakan untuk substansi penulisan berdasarkan sumber data dan informasi primer serta sumber informasi lain sebagai pendukung. Informasi primer diperoleh dari stakeholder/ partisipan yang terkait dengan penyelenggaraan SRG di Kabupaten Aceh Tengah. Sedangkan data dan informasi pendukung lainnya diperoleh dari berbagai sumber publikasi dan media

\section{HASIL DAN PEMBAHASAN}

\section{Penyelenggaraan dan Tinjauan Konsep Sistem Resi Gudang (SRG)}

Sistem Resi Gudang telah disosialisasikan oleh pemerintah sejak tahun 2008 agar menjadi lembaga yang memiliki sistem yang menyokong daya tawar petani dan efisiensi dibidang agribisnis. Sistem Resi Gudang memberikan jaminan keamanan bagi perbankan karena data dan informasi dipantau secara langsung oleh Badan Perdagangan Berjangka Komoditi (Bappebti). Selain itu juga pemilik barang maupun calon pemilik barang mendapatkan kepastian mutu karena adanya penyimpanan dan pengelolaan yang baik oleh Pengelola Gudang. Terdapat sepuluh jenis komoditas pertanian yang dapat disimpan di gudang SRG untuk dijadikan RG jaminan pada lembaga keuangan, yaitu gabah, beras, jagung, kopi, rumput laut, kakao, rotan, garam, lada, dan timah. Berdasarkan jenis komoditas, pada tahun 2020 penerbitan RG masih didominasi oleh gabah yaitu sebesar 2.763 RG atau $90 \%$ lebih banyak dibandingkan RG komoditas lainnya (Erwidodo et al., 2014)(Erwidodo et al., 2014).

Penyelenggaraan SRG di Indonesia terbukti mampu meningkatkan kualitas dan produktivias produk karena kegiatan usahatani dilakukan sesuai jadwal tanam dan pemasarannya dilakukan dengan lebih efektif. Sistem Resi Gudang juga menjadi sarana pembiayaan terbaik bagi petani karena mendapatkan sumber kredit meskipun tidak berpendapatan tinggi. pelaksanaan SRG memiliki peran penting karena menjadi pengontrol dalam aliran barang pada sebuah jaringan distribusi, terutama rantai pasok (Ramaa, Subramanya, \& Rangaswamy, 2012); (Ashari et al., 2013).

Konsep dasar yang berkaitan dengan penelitian ini meliputi: SRG, Resi Gudang (RG), pengelola, pengguna (kelompok tani, petani), fasilitas, serta kebijakan (pusat dan daerah )yang tercantum dalam perundang-undangan tentang SRG maupun dalam Permendag. Berdasarkan UU No. 9/2011, SRG adalah sistem yang mencakup kegiatan penerbitan, pengalihan, penjaminan, dan penyelesaian transaksi Resi Gudang (RG). Dokumen bukti kepemilikan atas barang yang disimpan di gudang yang diterbitkan oleh Pengelola Gudang disebut Resi Gudang. Resi Gudang digunakan untuk mendapatkan subsidi bunga dari pemerintah sebagai jaminan pada pihak bank yang diterbitkan oleh pengelola gudang. Peserta SRG adalah petani, kelompok tani, gabungan kelompok tani, koperasi, atau perusahaan swasta yang disetujui bank pelaksana.

Sejak dilaksanakan pada tahun 2008, Bappebti dibawah koordinasi Kementerian Perdagangan (Kemendag) yang bekerjasama Pemerintah Daerah telah membangun 59 gudang swasta dan 127 gudang pemerintah di 124 kabupaten dan 27 provinsi di Indonesia (Badan Pengawas Perdagangan Berjangka Komoditi [BAPPEBTI], 2020). Berdasarkan data yang diperoleh dari Badan Pengawas Perdagangan Berjangka Komoditi [BAPPEBTI] (2020), SRG mengalami peningkatan kinerja sejak tahun 2008 hingga tahun 2014. Hal ini dibuktikan dengan adanya peningkatan jumlah SRG sebanyak $1.873 R G$ yang telah diterbitkan hingga tahun 2014. Namun jumlah RG pada tahun 2020 justru mengalami penurunan yaitu hanya sejumlah 50 RG atau sebesar Rp36,7 Milyar. Penurunan drastis tersebut dikarenakan kurangnya kemampuan manajerial dan entrepreneurship dari pengelola SRG serta terjadinya gagal panen dibeberapa sentra produksi sehingga harga jual komoditas tinggi (Badan Pengawas Perdagangan Berjangka Komoditi [BAPPEBTI], 2020). Penurunan jumlah RG ini juga menunjukkan bahwa pelaksanaan SRG masih terbatas, meskipun mengalami peningkatan 6 tahun terakhir. Terdapat sekitar 50\% SRG yang tidak berjalan karena kurangnya dukungan pemerintah. Keberhasilan SRG juga diukur dari banyak jumlah RG yang terbit dan nilai pembiayaan yang diterima oleh penerima SRG.

Terdapat tiga konsep tentang infrastruktur penyelenggaran SRG yaitu 1) gudang, adalah ruangan yang tidak bergerak dan tidak dapat dipindah-pindahkan dan dipakai sebagai tempat penyimpanan barang yang dapat diperdagangkan secara umum dengan syarat yang telah ditetapkan oleh Menteri; 2) barang, adalah benda yang tidak bergerak yang dapat disimpan dalam jangka waktu tertentu dan diperdagangkan secara umum; 3) barang bercampur, yaitu barang-barang yang dianggap setara serta sama satuan unitnya dan dapat disimpan secara bercampur. Pemegang RG adalah pemilik barang atau pihak yang lain yang menerima pengalihan lebih lanjut. Sedangkan hak jaminan atas $R G$ adalah hak jaminan yang dibebankan untuk pelunasan utang. 
Provinsi Aceh memiliki empat daerah yang menerapkan SRG yaitu Kabupaten Aceh Tengah, Kabupaten Bener Meriah, Kabupaten Bireuen dan Kabupaten Pidie. Namun hanya di dataran tinggi Gayo yaitu di tiga kabupaten (Kabupaten Aceh Tengah, Kabupaten Bener meriah dan Gayo Lues) yang menerapkan program SRG komoditas kopi, khususnya kopi Arabika Gayo. Kabupaten Aceh Tengah memiliki jumlah produksi kopi Arabika Gayo terbesar setelah Kabupaten Bener Meriah, dan Kabupaten Gayo Lues yaitu 32.039 ton pada tahun 2018 (Badan Pusat Statistik, 2019). Tingginya produksi kopi Arabika Gayo menjadi peluang besar bagi pelaksanaan SRG. Hal ini juga didukung karena nilai jual kopi Arabika Gayo yang tinggi yaitu 30 hingga 50 US\$ lebih mahal dibanding jenis kopi arabika lainnya (Internasional Coffee Organization [ICO], 2015).

\section{Kinerja Pengelola Gudang SRG Arabika Gayo di Kabupaten Aceh Tengah}

Pengelola Gudang SRG perlu memiliki sumber daya manusia yang handal. Hal ini berkaitan dengan tanggung jawab Pengelola Gudang untuk menjaga mutu dan volume komoditi yang dititipkan oleh pemilik barang di dalam gudang. Pengelola Gudang memerlukan pemahaman tentang kewirausahaan agar pemasaran komoditas dapat dilakukan berdasarkan analisis dan pengembangan bisnis sehingga memberikan keuntungan yang maksimal.

Sistem Resi Gudang di Kabupaten Aceh Tengah awalnya dirintis oleh PT. Bhanda Ghara Reksa (BGR) namun sejak tahun 2014 digantikan oleh PT. Ketiara sebagai Pengelola Gudang sebab dianggap memiliki kemampuan manajemen yang lebih baik. PT. Ketiara merupakan sebuah perusahaan yang awalnya berbentuk koperasi di Kecamatan Bebesan, Kabupaten Aceh Tengah. Tingginya volume permintaan kopi Arabika Gayo dari luar negeri membuat PT. Ketiara menjadi Pengelola Gudang SRG terpilih oleh Bappebti.

PT. Ketiara merupakan salah satu perusahaan eksportir kopi Arabika Gayo dari 14 perusahaan eksportir kopi lainnya di Aceh. Sebesar 54\% kopi Arabika Gayo menjadi komoditi eksportir Aceh terbesar (non migas) dibandingkan Steam Coalin (22\%), Ammoniac (22\%) dan lainlain (2\%) (Dinas Perindustrian dan Perdagangan [DISPERINDAG], 2018). Adapun jumlah ekspor kopi yang dilakukan oleh PT. Ketiara sejak tahun 2014 hingga tahun 2017 ditunjukkan pada Tabel 1.

Tabel 1 Realisasi eskpor kopi arabika Gayo PT. Ketiara tahun 2014-2017

\begin{tabular}{ccc}
\hline Tahun & Volume (ton) & Nilai (US\$) \\
\hline 2014 & 163.20 & 986.880 \\
2015 & 337.48 & 205.104 .490 \\
2016 & 317.28 & 1.838 .338 \\
2017 & 235.80 & 1.413 .024 \\
\hline
\end{tabular}

Sumber: Disperindag Aceh (2018)

Berdasarkan data dari Dinas Perindustrian dan Perdagangan [DISPERINDAG], (2018) diatas, diketahui bahwa nilai ekspor kopi arabika Gayo oleh PT. Ketiara paling tinggi terjadi pada tahun 2015 yaitu sebesar 205.104.490 US\$. Hai itu terjadi karena harga jual greenbean ready export cukup tinggi yaitu berkisar Rp 60.000 - Rp 70.000,- per kg. Pasokan kopi di PT. Ketiara sebagian besar didominasi berasal dari dataran tinggi Gayo di Aceh (Kabupaten Aceh Tengah, Kabupaten Bener Meriah, dan Kabupaten Gayo Lues). Sejak aktif pada tahun 2014, PT. Ketiara telah melakukan skema bisnis yang menguntungkan bagi pengguna SRG, terutama petani. Selain itu, PT. Ketiara memproduksi kopi organik dengan rasa dan aroma yang berkualitas tinggi sehingga membuka banyak peluang bisnis dengan berbagai buyer yang tersebar dibeberapa negara diantaranya; Amerika Serikat, Hongkong, Jerman dan Saudi Arabia.

Tidak hanya mengutamakan pada keperluan bisnis, PT. Ketiara juga membina petani dibawah sertifikasi Control Union dan mendapatkan sertifikasi FLO-CERT sebagai Trader dan Processor. Kinerja PT. Ketiara sebagai pengelola gudang meningkatkan kinerja SRG komoditas kopi di Provinsi Aceh. Menurut data Badan Pengawas Perdagangan Berjangka Komoditi [BAPPEBTI], (2020), jumlah RG kopi hingga tahun 2020 adalah sebanyak $37 R G$ atau setara dengan nilai pembiayaan 27,2 Milyar. Nilai pembiayaan ini hampir mencapai $50 \%$ dari nilai pembiayaan RG komoditas kopi nasional sejumlah 59 Milyar. Berdasarkan rekapitulasi transaksi per komoditi Badan Pengawas Perdagangan Berjangka Komoditi [BAPPEBTI] (2020), tahun 2008 hingga tahun 2020, komoditas kopi adalah komoditas dengan transaksi RG tertinggi ke empat setelah gabah, beras, dan jagung. Proporsi transaksi RG komoditi kopi nasional didominasi dari kinerja SRG kopi Arabika Gayo di Provinsi Aceh, khususnya di Kabupaten Aceh Tengah. Data ini membuktikan bahwa sebenarnya prospek kemajuan SRG sangat tinggi dan berpotensi terus berkembang.

Persyaratan komoditi yang dapat disimpan di gudang SRG yang dikelola PT. Ketiara adalah 1) Memiliki daya simpan paling sedikit tiga bulan, 2) Memenuhi standar mutu tertentu dan 3) Jumlah 
minimum komoditi yang tersimpan. Berdasarkan persyaratan tersebut, maka komoditas kopi Arabika Gayo yang dapat disimpan di gudang SRG harus miliki kualitas yang terjamin dan tersertifikasi sesuai standar mutu yang ditetapkan. Varietas Kopi Arabika yang dibudidayakan petani di dataran tinggi Gayo cukup beragam, seperti: Bergendal, Gayo 1, Gayo 2, P-88, Sidi Kalang, Rambung, Lini S (Jember), USDA, Catimor Jaluk (Ateng Jaluk), Ateng Super, BP 542, C50, dan lainnya \{Tambarta, (2017); Fadhiela et al., (2018)\}. Akan tetapi yang direkomondasikan Pemerintah Daerah hanya tiga varietes yaitu: Gayo 1, Gayo2 dan P-88. Kopi Arabika Gayo yang dimasukkan di Gudang SRG harus memiliki daya simpan minimal 3 bulan dan tergolong pada kopi arabika Grade 1 dan Grade 2 dalam bentuk greenbean.

Penyimpanan kopi di gudang SRG harus secara kolektif melalui kelompok tani. Selain itu, jumlah minimum yang harus dipenuhi kelompok tani agar dapat disimpan di gudang yaitu 10 ton. Petani harus bergabung dalam suatu kelompok tani agar setiap kelompok memenuhi syarat minimal penyimpanan. Hasil penelitian menunjukkan bahwa hal ini merupakan kesulitan bagi petani kopi Arabika Gayo di Kabupaten Aceh Tengah karena tidak semua petani menghasilkan panen yang banyak dan berkualitas tinggi. Tingginya standar kopi tersebut menjadi kendala bagi banyak petani di Kabupaten Aceh Tengah. Fadhiela et al., (2018) dan Tambarta, (2017) menyatakan bahwa proses grading kopi yang dianggap terlalu lama membuat petani enggan terlibat di SRG. Selain karena proses menghabiskan waktu yang lama dan membutuhkan biaya proses yang tinggi, petani kopi Arabika Gayo di Kabupaten Aceh Tengah juga tidak memiliki pasar yang tepat untuk kopi grade 1 atau grade 2. Faktor ini yang membuat sebagian besar petani tidak berpartisipasi pada pelaksanaan SRG di Kabupaten Aceh Tengah.

Sebaliknya, penyimpanan dan pemeliharaan, penerbitan resi gudang serta pemeliharaan aset gudang yang menjadi bagian penting PT. Ketiara sudah dilakukan dengan baik. Tahap promosi transaksi resi gudang juga dilakukan oleh Pengelola Gudang. Pada proses pelaksanaan SRG, Pengelola Gudang melakukan koordinasi dengan berbagai pihak seperti kelompok tani, lembaga uji kesesuaian, lembaga penjamin, dan pusat registrasi. Bahkan sejak tahun 2017, PT. Ketiara dipercayakan oleh Bappebti sebagai lembaga resmi yang menguji fisik dan cita rasa untuk komoditas kopi di Kabupaten Aceh Tengah. Sebelumnya pada tahun 2016 pengujian uji mutu dilakukan oleh BPSMB di Kota Banda Aceh. Proses ini membuktikan bahwa PT. Ketiara selaku Pengelola Gudang telah melakukan sistem bisnis yang menguntungkan karena mampu memutus biaya transaksi dan meningkatkan nilai tambah produk kopi secara mandiri. Meskipun demikian, pelaksanaan SRG perlu dilakukan pengawasan internal agar program berjalan sesuai dengan ketentuan. Adapun SOP berdasarkan informasi dari PT. Ketiara dalam pelaksanaan SRG, yaitu:

1. Pemilik barang mengajukan surat permohonan kepada pengurus gudang SRG PT. Ketiara untuk menyimpan barang.

2. Pimpinan gudang SRG PT. Ketiara mengirimkan bukti konfirmasi telah diterbitkannya Resi Gudang melalui SRG-Online.

3. PT. Ketiara wajib melaporkan Resi Gudang yang dinyatakan tidak berlaku oleh Pengelola Gudang kepada Pusat Registrasi dan Bappebti serta Penerima Hak Jaminan (Bank BRI) apabila Resi Gudang dibebani hak jaminan (diagunkan)

4. PT. Ketiara memastikan pemilik Resi Gudang telah menyerahkan Resi Gudang asli sebelum pengeluaran barang.

5. Setiap pengambilan barang baik keseluruhan maupun sebagian terhadap Resi Gudang yang dijaminkan harus menyerahkan bukti persetujuan pengeluaran barang dari Bank BRI kepada PT. Ketiara.

6. PT. Ketiara wajib membuat laporan bulanan, triwulan, dan tahunan yang disampaikan kepada Bappebti yang memuat pembukuan dan catatan kegiatan yang berkaitan dengan SRG.

7. Pelaksana gudang melakukan evaluasi setiap triwulan mengenai barang yang disimpan di gudang, infrastruktur, dan melaporkan kepada pimpinan gudang SRG PT. Ketiara.

Berdasarkan observasi di lapangan, SOP yang telah ditetapkan oleh Pengelola Gudang tersebut telah dijalankan sebagaimana mestinya. Hanya saja proses akan terlambat apabila koneksi internet bermasalah ataupun penanggung jawab administrasi PT. Ketiara berhalangan hadir. Meskipun demikian, hubungan Pengelola Gudang dan pusat registrasi tetap berjalan karena adanya Sistem Informasi Resi Gudang Pusat Registrasi (IS-WARE) yang menjadi sistem komunikasi yang efektif. Segala transaksi resi gudang meliputi pengalihan, pembebanan hak jaminan, dan penyelesaian transaksi dicatat oleh sistem IS-WARE. 


\section{Kinerja Pengguna SRG}

Pengguna SRG kopi Arabika Gayo di Kabupaten Aceh Tengah sejak tahun 2015 didominasi oleh kelompok tani. Pada tahun 2017, terdapat 40 orang yang terdiri dari 5 kelompok tani yang ikut serta dalam program SRG. Total luas kebun yang dimiliki seluruh petani yang bergabung yaitu 48 hektar dengan rata-rata luas lahan yang dimiliki yaitu 1.27 hektar. Berdasarkan jumlah produksi, ratarata hasil panen yang diperoleh dan disimpan di gudang SRG yaitu $1.3 \mathrm{~kg}$ (Fadhiela et al., 2018). Jika dibandingkan dengan jumlah petani kopi di Kabupaten Aceh Tengah, jumlah penyimpanan ke gudang SRG ini sangat sedikit. Tidak seluruh petani memanfaatkan SRG sebagai saran untuk mendapatkan pembiayaan atau pemasaran kopi Arabika Gayo.

Berdasarkan data dari Badan Pengawas Perdagangan Berjangka Komoditi [BAPPEBTI], (2017), bahwa jumlah volume komoditas kopi yang terdaftar pada transaksi Resi Gudang paling tinggi pada tahun 2015. Hal ini dikarenakan nilai jual kopi Arabika yang tinggi dan banyak kelompok tani yang mulai berpartisipasi aktif pada pelaksanaan SRG di daerah tersebut. Namun tingginya volume kopi dan jumlah pembiayaan dari perbankan masih menunjukkan bahwa minat para petani terlibat pada pelaksanaan di SRG kopi di Kabupaten Aceh Tengah sangat rendah. Menurut penelitian (Fadhiela et al., 2018), jumlah penerbitan Resi Gudang kopi fluktuatif tiap tahun dan sangat kecil yaitu hanya $0.15 \%$ dibandingkan jumlah total produksi kopi Arabika Gayo di Kabupaten Aceh Tengah.Terdapat beberapa alasan kenapa perlu ada keterlibatan petani pada kegiatan SRG di Kabupaten Aceh Tengah, yaitu pembayaran dan pembiayaan yang tepat dan mudah, adanya jaminan keamanan barang, dan adanya kontrak dengan Pengelola Gudang. Namun kondisi di lapangan menunjukkan bahwa masih banyak petani yang justru memilih jasa kolektor untuk mendapatkan kredit meskipun harga yang diterima petani lebih rendah. Hal ini sangat disayangkan karena pada dasarnya pembiayaan melalui perbankan pada SRG lebih mudah dan terjamin. Selama ini program SRG di Kabupaten Aceh Tengah hanya dimanfaatkan oleh petani yang sudah bergabung dalam kelompok tani dan memiliki hasil panen yang lebih tinggi karena dikumpulkan secara kolektif.

Salah satu syarat didirikannya gudang SRG adalah harus berstandar SNI baik dalam segi keamanan maupun perawatan kopi yang telah tersimpan. Oleh karena itu, jika terdapat kerusakan mutu barang (kopi) maka seutuhnya menjadi tanggung jawab Pengelola Gudang kecuali jika terjadi kebakaran. Bencana kebakaran telah menjadi tanggung jawab Lembaga Penjamin Resi Gudang (pihak asuransi). Secara umum fasilitas gudang di Kabupaten Aceh Tengah masih belum memadai sehingga adanya keterjaminan mutu dan keamanan barang menjadi daya pikat utama petani yang akan memanfaatkan SRG (Tambarta, 2017).

Sistem bisnis yang dilaksanakan pada SRG kopi Arabika Gayo di Kabupaten Aceh Tengah menggunakan sistem kontrak komoditi. Sistem ini memberikan keuntungan bagi petani peserta SRG yang menyimpan barang (kopi) secara kolektif (minimal 10 ton kopi per kelompok). Keuntungan yang diberikan pada para petani yaitu adanya kepastian pembelian oleh standby buyer yang telah bekerja sama dengan Pengelola Gudang. Oleh karena itu, petani yang ikut menyimpan dan menjalani semua proses administrasi pada program SRG tidak hanya menjadi konsumen tapi juga rekan bisnis penting bagi Pengelola Gudang. Pola ini digunakan untuk menguatkan permodalan pelaku usaha dengan kredit SRG untuk memenuhi target kontrak yang telah disepakati bersama atau jumlah kontrak yang akan dibeli oleh standby buyer. Pola komoditi seperti ini sangat memberikan keuntungan pada pengguna SRG (petani) karena petani tidak perlu menunda jual karena sudah terikat kontrak melalui pengelola gudang yang terhubung dengan standby buyer sebelumnya. Berikut skema pola pembiayaan komoditi kopi Standby Buyer (kontrak dengan pelaku usaha besar).

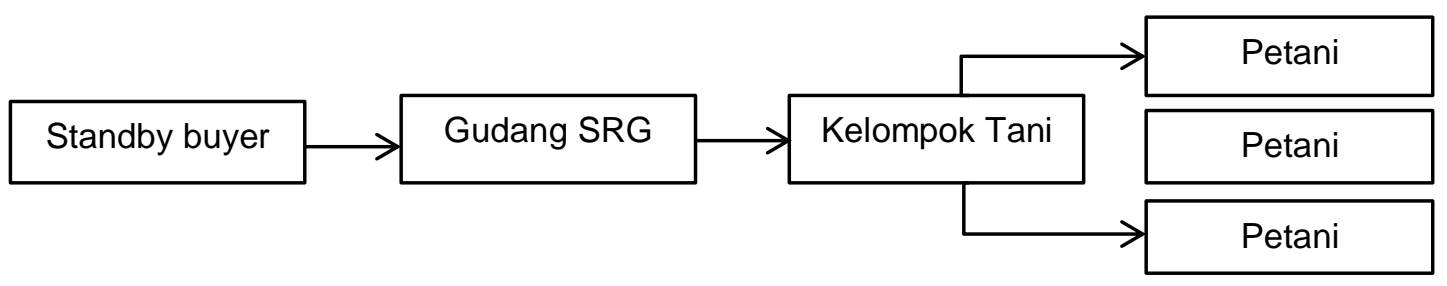

Gambar 1. Skema pola pembiayaan komoditi kopi Standby Buyer

Berdasarkan pola bisnis tersebut, petani kopi mendapatkan keuntungan lebih besar dikarenakan adanya jaminan pembelian atas barang yang disimpan. Asumsi profit yang diperoleh oleh petani kopi jika menyimpan kopi sebanyak 1 ton adalah sebesar Rp 31.188/kg dengan masa simpan kopi di gudang SRG selama 3 bulan (Fadhiela et al., 2018). Keuntungan memanfaatkan SRG ini bahkan lebih besar jika dibandingkan dengan keuntungan petani kopi jika memanfaatkan pinjaman atau jasa kredit dari pedagang yaitu sebesar Rp 17.911 kg (Iski, Kusnadi, \& Harianto, 2016). Adapun 
biaya-biaya yang seharusnya ditanggung oleh petani tetapi disubsidi oleh Pengelola Gudang, antara lain sebagai berikut: biaya asuransi, biaya registrasi dan ppn $10 \%$, Bunga bank $0.5 \%$ dari pembiayaan, biaya uji umur, biaya handling, biaya transportasi, biaya keamanan, biaya perawatan, biaya penyimpanan dan biaya transaksi.

Berbeda komoditi, berbeda pula pola pembiayaan yang diterapkan pada SRG. Komoditi gabah misalnya, Zulkarnain (2017), menemukan bahwa motivasi terbesar petani padi menyimpan gabah di gudang SRG Kabupaten Bantul yaitu karena adanya sistem tunda jual. Ini dibuktikan dengan adanya peningkatan pendapatan sebesar $16 \%-25 \%$ penjualan gabah yang lebih tinggi dibandingkan petani yang tidak memanfaatkan SRG. Melalui sistem tunda jual, petani akan mendapatkan permodalan usaha dengan adanya kredit SRG. Hal serupa juga dinyatakan oleh (Masithoh, 2016) bahwa keuntungan petani peserta SRG Gabah yang melakukan tunda jual di Kabupaten Cianjur di yaitu rata-rata Rp248.37. Meskipun demikian, keuntungan ini tergantung pengaruh lama simpan dan fluktuasi harga gabah itu sendiri.

\section{Kebijakan Kementerian Perdagangan, Pemerintah Daerah, dan Lembaga Pembiayaan}

Terkait dengan peran dan fungsi Pemerintah Daerah, maka peran Pemerintah Daerah dalam hal pengembangan SRG meliputi 1) pembuat kebijakan untuk percepatan pelaksanaan SRG, 2) pengembangan komoditas unggulan di daerah, 3) penguatan peran pelaku usaha ekonomi, dan 4) fasilitasi pengembangan pasar lelang komoditas. Urusan Pemda di bidang pembinaan SRG dikoodinasi dengan Badan Pengawas. Badan Pengawas Perdagangan Berjangka Komoditi (Bappebti) adalah lembaga yang berwenang melakukan pengawasan, pembinaan, dan pengaturan pelaksanaan sistem resi gudang. Gudang SRG dan Pengelola Gudang direkomendasi oleh Dinas Perdagangan sehingga peran stakeholder ini sangat berpengaruh pada pengawasan kinerja SRG di daerah setempat. Sistem Resi Gudang menjadi salah satu instrumen pengukuran ketersediaan stok pangan nasional. Instrumen ini dapat dipantau melalui IS-WARE yang dapat mendata jumlah ketersediaan komoditas diberbagai daerah yang melaksanakan SRG. Melalui SRG, pemerintah mengetahui ketersediaan komoditi di setiap wilayah lokasi gudang SRG sehingga menjadi alat bantu pemerintah mengambil kebijakan terkait distribusi dan penyediaan bahan pangan di daerah.

Dinas Perindustrian, Perdagangan, dan Koperasi (Disperindagkop) Kabupaten Aceh Tengah dan Bank BRI Takengon merupakan lembaga yang berperan penting dalam hal kebijakan dan monitoring pelaksanaan SRG. Bank BRI Takengon memberikan pinjaman (kredit) bagi kelompok tani yang menyimpan barang di gudang SRG dengan memberikan pembiayaan sebesar $70 \%$ dari harga jual barang yang disimpan. Sistem pembiayaan ini menguntungkan petani sehingga petani tidak perlu kesulitan akan jaminan lainnya. Petani hanya perlu mengumpulkan barang (kopi) sesuai SNI yang telah ditetapkan oleh Pengelola Gudang dan mengurus segala keperluan administrasi SRG.

Sejak tahun 2020, Kemendag melakukan kerja sama dengan bank lain selain Bank BRI yaitu Bank Aceh. Kemendag juga melakukan sosialisasi dan pelatihan pelaksanaan pembiayaan SRG khususnya terkait skema pembiayaan yang bersifat syariah. Kerjasama ini memberikan manfaat agar pelaksanaan pembiayaan SRG semakin meluas dan cepat karena pihak bank mencairkan pembiayaan RG karena nilai pembiayaan resi yang sangat besar. Kehadiran bank lokal seperti Bank Aceh akan meningkatkan kepercayaan masyarakat. Menurut Zulkarnain (2017), pembiayaan SRG yang berlandaskan syariah dapat meningkatkan kesejahteraan masyarakat terutama petani karena skema transaksi keuangan bebas dari suku bunga tinggi atau riba. Waktu penyimpanan barang 3 hingga 4 bulan tidak bertujuan untuk menahan barang supaya terjadi kelangkaan, tetapi bertujuan untuk menghasilkan keuntungan pada selisih harga yang sedikit lebih tinggi. Maka dapat disimpulkan bahwa SRG sangat cocok dilaksanakan dengan sistem syariah. Kerja sama tersebut menjadi bentuk respon terhadap aktivitas perkembangan pembiayaan SRG di Provinsi Aceh. Oleh karena itu sejak Juni 2020 pembiayaan SRG juga dapat dilakukan di Bank Aceh sesuai aturan yang berlaku.

Kemendag sebagai kementerian yang menaungi Bappebti, sejak tahun 2020 telah memberikan stimulus Dana Alokasi Khusus (DAK) untuk daerah agar memperluas implemantasi SRG. Salah satu daerah yang menerima DAK tahun 2020 adalah Kabupaten Aceh Tengah. Intervensi Kemendag melalui pengalokasian DAK ini penting untuk menstimulus dan mengoptimalkan manfaat dari implementasi SRG.

Dukungan Kemendag untuk pengembangan SRG sangat penting dilakukan. Segala kebijakan yang dilakukan oleh Pemerintah juga membutuhkan partisipasi para petani. Oleh karena itu, Kemendag melakukan pendekatan kepada Penyuluh Pertanian untuk memahami mekanisme, dan manfaat SRG sehingga dapat berperan dalam mengedukasi, membimbing, dan mengawal petani dalam memanfaatkan gudang SRG. Kerja sama yang dilakukan dengan melibatkan Penyuluh Pertanian sudah berjalan di Jawa Tengah, tapi belum terlaksana di Kabupaten Aceh Tengah. Oleh karena itu, Kemendag perlu melakukan hal serupa di Kabupaten Aceh Tengah. 
Dinas Perindustrian, Perdagangan, dan Koperasi (Disperindagkop) Kabupaten Aceh Tengah sebagai stakeholder yang juga berperan penting terhadap kelancaran SRG telah melakukan sosialisasi di tingkat petani dan kelompok tani. Namun aktivitas pembinaan yang dilakukan Disperindagkop tidak sepenuhnya optimal. Hal ini dikarenakan Disperindagkop belum melakukan kebijakan aksi yang berkaitan dengan implementasi SRG secara keseluruhan pada petani. Buktinya hanya $15 \%$ hingga $20 \%$ petani kopi yang berpartisipasi pada SRG kopi Arabika Gayo di Kabupaten Aceh Tengah. Padahal keterkaitan pelaksanaan SRG dengan Pemda diatur melalui UU No. 9/2006 dan perubahannya, Pemda sebagai pembuat kebijakan bertugas untuk mempercepat keunggulan di daerah, penguatan peran pelaku usaha ekonomi kerakyatan, dan fasilitas pengembangan pasar lelang komoditas (Anugrah et al., 2015).

Selama ini Disperindagkop bersama Bank BRI dapat memonitor pelaksanaan SRG secara langsung melalui fasilitas keamanan seperti satpam dan CCTV yang juga terintegrasi langsung ke kantor Bappebti. Petani tidak diperbolehkan memonitor secara langsung kopi yang telah masuk gudang. Hal tersebut memberi keyakinan kepada petani atas keamanan kopi yang disimpan di gudang SRG

\section{KESIMPULAN DAN SARAN}

Tingginya produksi kopi Arabika Gayo menjadi peluang besar bagi pelaksanaan SRG. Proporsi transaksi RG komoditi kopi nasional didominasi dari kinerja SRG kopi Arabika Gayo di Provinsi Aceh, khususnya di Kabupaten Aceh Tengah. Jumlah RG hingga tahun 2020 adalah sebanyak 37 RG atau setara dengan nilai pembiayaan 27,2 Miliar. Nilai pembiayaan ini hampir mencapai $50 \%$ dari nilai pembiayaan RG komoditas kopi nasional sejumlah 59 Miliar. Proporsi transaksi RG komoditi kopi nasional didominasi dari kinerja SRG kopi Arabika Gayo di Provinsi Aceh, khususnya di Kabupaten Aceh Tengah. Data ini membuktikan bahwa sebenarnya prospek kemajuan SRG sangat tinggi dan berpotensi terus berkembang

Sistem bisnis yang dilaksanakan Pengelola Gudang pada SRG kopi Arabika Gayo di Kabupaten Aceh Tengah menggunakan sistem kontrak komoditi. Pola komoditi seperti ini sangat memberikan keuntungan pada pengguna SRG (petani) karena petani tidak perlu menunda jual karena sudah terikat kontrak penjualan melalui pengelola gudang yang terhubung dengan standby buyer sebelumnya. Hingga saat ini, PT. Ketiara telah melakukan sistem yang baik dalam segi bisnis, termasuk telah menjalankan SOP SRG sebagaimana mestinya.

Hasil pendekatan dari kinerja pengguna SRG yaitu petani, diketahui bahwa meskipun nilai pembiayaan yang diperoleh para petani kopi Arabika Gayo dari bank relatif tinggi ternyata hal tersebut tidak menjadi indikator keberhasilan pelaksanaan SRG di Kabupaten Aceh Tengah. Pada pelaksanaannya di lapangan, tidak semua petani kopi Arabika Gayo memanfaatkan SRG. Banyak petani yang justru memilih jasa kolektor untuk mendapatkan kredit meskipun harga yang diterima petani lebih rendah. Jumlah penerbitan Resi Gudang kopi fluktuatif tiap tahun dan sangat kecil yaitu hanya $0.15 \%$ dibandingkan jumlah total produksi kopi Arabika Gayo di Kabupaten Aceh Tengah.

Dilihat dari segi pembiayaan kelembagaan keuangan, Bappebti telah bekerja sama dengan pihak bank lokal yaitu Bank Aceh untuk mendukung program pembiayaan SRG. Hal ini merupakan sisi positif yang membuktikan bahwa SRG kopi Arabika Gayo di Kabupaten Aceh Tengah memperhatikan sisi pembiayaan SRG bagi pengguna SRG. Hingga kini fasilitas pergudangan, pengeringan, pengemasan pada skema SRG kopi Arabika Gayo di Kabupaten Aceh Tengah tidak memiliki masalah yang berarti. Kegiatan usaha yang dikelola oleh Pengelola Gudang tetap perlu didukung terutama dalam peningkatan sarana dan prasarana.

Sosialisasi dari Pemerintah Daerah maupun pihak lainnya yang berkaitan dengan kegiatan SRG belum seutuhnya dijalankan meskipun telah bekerja sama dengan Penyuluh Pertanian untuk menjalankan SRG. Tidak semua petani kopi memiliki hasil panen yang melimpah dan terlibat pada kelompok tani sehingga jumlah barang yang masuk di gudang SRG juga masih sedikit. Selain itu, Pengelola Gudang SRG sampai saat ini hanya fokus pada satu perusahaan lokal yaitu PT. Ketiara saja sehingga peluang untuk mengembangkan SRG di daerah Kabupaten Aceh Tengah juga masih kecil.

Kopi yang diperbolehkan masuk gudang SRG untuk dijadikan jaminan harus berstandar SNI yaitu berupa green bean dan telah melewati segala pengujian kadar air, mutu dan sebagainya. Pemenuhan standar ini masih dianggap berat oleh petani biasa karena hasil panen belum tentu berkualitas tinggi. Oleh karena itu, seharusnya Pemda benar-benar dapat mengubah mindset petani terhadap pemasaran komoditas pertanian, penyediaan fasilitas akses permodalan, penyediaan sarana prasarana SRG, serta mendorong lembaga keuangan bank sebagai mitra pembiayaan pengembangan SRG. 
Pelaksanaan SRG di Kabupaten Aceh Tengah selama ini hanya dimanfaatkan oleh beberapa petani yang sudah terlebih dahulu bersinergi dengan Pengelola Gudang. Seharusnya iklim bisnis ini dapat dinikmati oleh semua petani kopi di Kabupaten Aceh Tengah. Pola bisnis SRG juga sebaiknya melibatkan lebih banyak Pengelola Gudang lainnya sehingga terciptanya iklim perekonomian lokal yang aktif dan kompetitif.

Dukungan dan peran aktif pemerintah daerah pada pengembangan usaha SRG juga perlu ditingkatkan dalam hal penyediaan sarana gudang dan koordinasi yang semakin baik dengan Bappebti dan Kementerian Pertanian. Koordinasi yang sinergi antar pihak pada sistem SRG akan memunculkan produktivitas SRG yang semakin baik. Saran yang bisa dilakukan pemerintah di masa yang akan datang adalah mengintegrasikan SRG dengan Pasar Lelang. Meskipun pelaksanaan ini masih sulit dikarenakan perlu mekanisme yang jelas terkait kelembagaan, keamanan, dan profesionalitas dari berbagai pihak. Sejauh ini belum ada integrasi SRG dan Pasar Lelang yang berjalan optimal dan efektif akibat belum terbukanya mindset petani dan pelaku usaha terkait. Diharapkan perbaikan atas permasalahan-permasalahan tersebut dapat menjadi kunci sukses dalam mempercepat penyebarluasan dan penyelenggaraan SRG di Kabupaten Aceh Tengah.

\section{REFERENSI}

Anugrah, I. S., Ewidodo, \& Suryani, E. (2015). Sistem Resi Gudang dalam Perspektif Kelembagaan Pengelola dan Pengguna di Kabupaten Subang: Studi Kasus KSU Annisa. Analisis Kebijakan Pertanian, 13(1 Juni 2015), 55-73.

Ariyani, R. R. (2008). Sistem Resi Gudang akan Diberlakukan Nasional.

Ashari. (2012). Potensi dan Kendala Sistem Resi Gudang (SRG) untuk Mendukung Pembiayaan Usaha Pertanian di Indonesia, 29 No 2(Desember 2011), 129-143.

Ashari, E., A., Y., S., A., R. C., \& Suharyono S. (2013). Kajian Efektivitas Sistem Resi Gudang dalam Stabilisasi Pendapatan Petani. Laporan Kegiatan Kajian Isu-Isu Aktual.

Badan Pengawas Perdagangan Berjangka Komoditi [BAPPEBTI]. (2017). Rekapitulasi Transaksi Resi Gudang di Kabupaten Aceh Tengah Tahun 2014-2017.

Badan Pengawas Perdagangan Berjangka Komoditi [BAPPEBTI]. (2020). Rekapitulasi Transaksi Resi Gudang Indonesia Tahun 2008-2020.

Badan Pusat Statistik. (2019). Provinsi Aceh Dalam Angka. Aceh (ID): BPS.

Dinas Perindustrian dan Perdagangan [DISPERINDAG]. (2018). Realisasi Ekspor dan Impor Provinsi Aceh 2011-2017.

Direktorat Jenderal Perkebunan [DITJENBUN]. (2019). Outlook Komoditas Kopi. Ditjenbun. Jakarta.

Erwidodo, Suryani, E., \& Anugrah, I. S. (2014). Kinerja dan Kendala Sistem Resi Gudang di Indonesia.

Fadhiela, K., Rachmina, D., \& Winandi, R. (2018). Biaya Transaksi dan Analisis Keuntungan Petani Pada Sistem Resi Gudang Kopi Arabika Gayo di Kabupaten Aceh Tengah, 6(1), 49-60.

Haryotejo, B. (2013). Analisis Korelasi Faktor yang Mempengaruhi Implementasi Sistem Resi Gudang (SRG) di Daerah. Jurnal Bina Praja, 5(juni 2013), 91-100.

Internasional Coffee Organization [ICO]. (2015). Historical Data On Global Coffee Trade. Diakses pada March 1, 2015, melalui http://www.ico.org/new_historical.asp?section=Statistics

Iski, N., Kusnadi, N. dan, \& Harianto. (2016). Pengaruh Kredit Terhadap Pendapatan Petani Kopi Arabika Di Kabupaten Aceh Tengah Provinsi Aceh. Jurnal Manajemen \& Agri Bisnis, 13(No 2, Juli 2016), 132-144. http://doi.org/10.17358/JMA.13.2.132

Masithoh, D. (2016). Biaya Transaksi Sistem Resi Gudang Gabah. Institut Pertanian Bogor (IPB).

Ramaa, A., Subramanya, k. ., \& Rangaswamy, T. (2012). Impact of Warehouse Management System in a Supply Chain. International Journal of Computer Application, 54(1), 14-20.

Tambarta, E. (2017). Analisis Nilai Tambah dan Strategi Pengembangan Olahan Kopi Arabika di Kabupaten Bener Meriah Aceh. Institut Pertanian Bogor (IPB).

Zulkarnain, L. (2017). Analisis Transaksi Resi Gudang dan Potensi Pengembangannya ke Unit Syariah. Jurnal Ekonomi Dan Perbankan Syariah, 5(1), 97-113. 